\title{
Blood neurofilament light chain at the doorstep of clinical application
}

David Leppert, MD, and Jens Kuhle, MD, PhD

Neurol Neuroimmunol Neuroinflamm 2019;6:e599. doi:10.1212/NXI.0000000000000599

\author{
Correspondence \\ Dr. Kuhle \\ jens.kuhle@usb.ch \\ or Dr. Leppert \\ david.leppert@unibas.ch
}

\section{RELATED ARTICLE}

High serum neurofilament light chain normalizes after hematopoietic stem cell transplantation for MS

Page e598
Neurofilaments are intracellular cytoskeletal proteins that are categorized according to their molecular weight in light, medium, and heavy chain types. Neuronal damage results in leaking of this protein into the extracellular space and eventually into CSF and blood. Neurofilament light chain (NfL) has been established in recent years as a biomarker (1) to quantify acute disease activity, (2) to monitor therapy response, and (3) to predict the course of disability and of brain and spinal cord atrophy ${ }^{2-6}$ in pharmacologically treated relapsing-remitting MS (RRMS) and progressive MS (PMS). Based on the strong correlation between CSF and plasma or serum measures, NfL is now at the doorstep to become the first biomarker that is applicable in clinical routine setting for longitudinal measurements based on blood sampling, a minimally invasive procedure.

In this issue of Neurology: Neuroimmunology \& Neuroinflammation, Thebault et al. ${ }^{1}$ used a highly sensitive digital ELISA (single molecule array) to test whether NfL results from pharmacologically treated MS cohorts can be replicated in a patient cohort with aggressive MS that underwent SCT. They found that ${ }^{1}$ as a retrospective correlation, NfL baseline levels in serum and CSF were associated with referring disability scores and recent prior relapse activity, and ${ }^{2}$ as a prospective correlation, the above median levels of $\mathrm{NfL}$ were found associated with a higher probability for sustained Expanded Disability Status Scale progression and worse outcome of cognitive function and quality of life scores. This was paralleled by higher scores for brain lesional volume and the course of atrophy over an observation period of 36 months, both by categorical and individual patient analysis. A novel finding in their study is that above median NfL levels correlated with the NAA/Cr ratio in MR spectroscopy, a measure of brain-diffuse neuronal loss. ${ }^{3}$ Although SCT led to a decrease in serum NfL levels in the entire cohort, the patient group that experienced disease progression after SCT had higher serum NfL levels 12 months after intervention than that with stabilized disability. Again, this was paralleled by the correlation of brain white matter atrophy and NfL levels. As no clinical or MRI signs for confounding acute disease activity were observed in this cohort after SCT, NfL levels can be seen as direct reflection of progressive disease. The study of Thebault et al. provides further support for NfL being a biomarker of therapeutic response in both directions, i.e., to assess the 


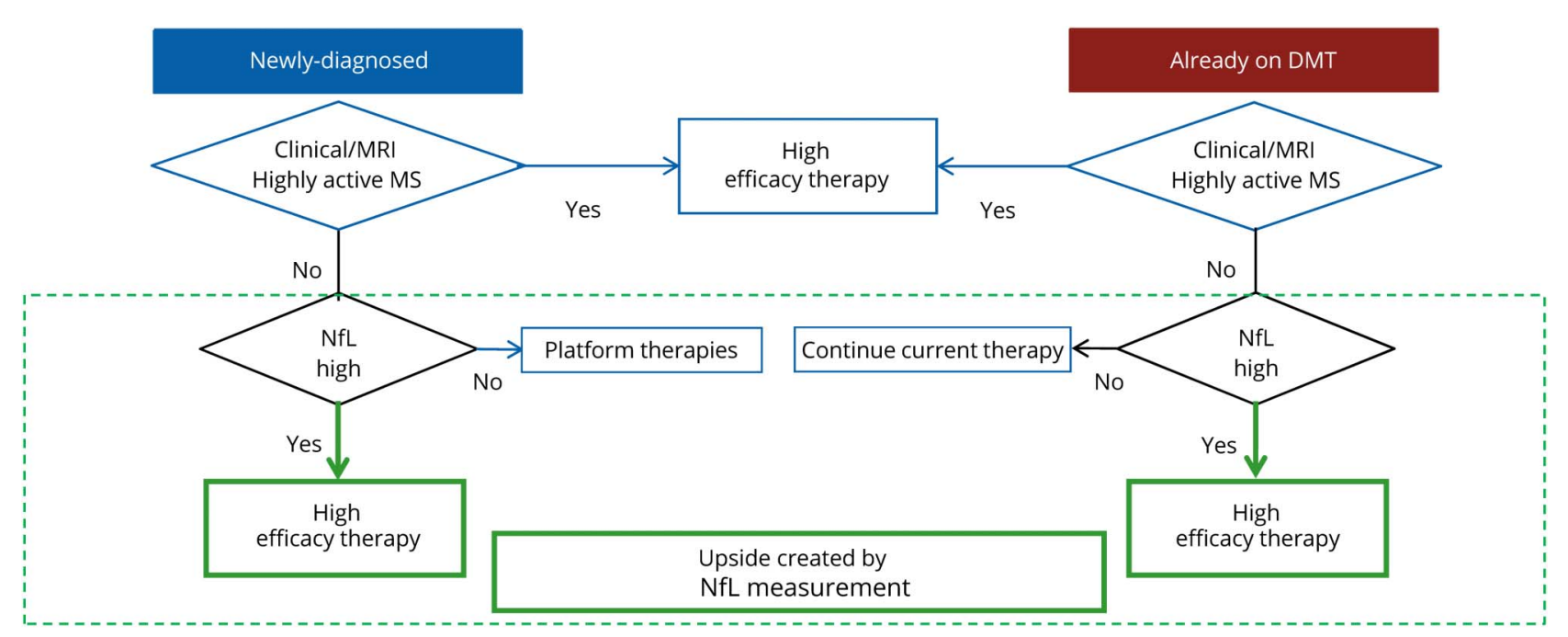

Hit hard/hit early: Expanding use of high efficacy therapies.

First-line in patients who look stable, but are not, as they have high rate of neuronal loss

DMT = disease-modifying therapy; $N f L=$ neurofilament light chain.

effect of an intervention and to indicate insufficient effect, which may qualify $\mathrm{NfL}$ as a surrogate trial end point. ${ }^{7}$

At first glance, the findings of coherent lowering of NfL levels after SCT and predictive capacity of baseline levels for future clinical and MRI features of disease progression seem paradoxical. However, the concept of "therapeutic lag"8 provides an elegant explanation where worsening disability in progressive MS is primed by past inflammation. Hence, the inflammation suppressing activity of DMT or SCT will have no immediate impact on worsening disability over the next 1 or 2 years, as the damage priming progression over this time has already occurred. Hence, all anti-inflammatory therapies will have a lag of translating the decrease of NfL into a clinically measurable result in terms of stabilizing progression in MS over time.

What is the practical application of the current report by Thebault and other studies in pharmacologically treated RRMS and PMS in clinical trials and retrospective cohorts? We envisage that based on its capacity and profile as a biomarker, NfL may be used in the future as an additional paraclinical measure for physicians in charge of therapeutic decisions, both for treatment initiation and modification (figure). NfL will not replace clinical and MRI-based evaluation, but it will shed light on disease activity that escape detection by the standard diagnostic armamentarium.

Still, there are important hurdles for the immediate use of serum NfL in routine clinical practice. We lack a database of normal values, particularly on the background of the age dependency of values. Second, there is currently no assay standardization or commutability between the various assay protocols. Efforts are underway to address these points in the coming years. If successful, we envisage $\mathrm{NfL}$ to become the first biofluid marker applicable as personalized medicine tool in MS.

\section{Study funding}

No targeted funding reported.

\section{Disclosure}

The authors report no disclosures. Disclosures available: Neurology.org/NN.

\section{References}

1. Thebault S, Tessier D, Lee H, et al. High serum neurofilament light chain normalises after haematopoietic stem cell transplant for MS. Neurol Neuroimmunol Neuroinflamm 2019;6:e598. doi: 10.1212/NXI.0000000000000598.

2. Barro C, Benkert P, Grobke S, et al. Serum neurofilament light chain correlates with disease activity and predicts clinical and MRI outcomes in MS. Mult Scler J 2017;23: 297-298.

3. Berger T, Stuve O. Neurofilament light chain: an important step toward a disease biomarker in multiple sclerosis. Neurology 2019;92:451-452.

4. Disanto G, Barro C, Benkert P, et al. Serum neurofilament light: a biomarker of neuronal damage in multiple sclerosis. Ann Neurol 2017;81:857-870.

5. Khalil M, Teunissen CE, Otto M, et al. Neurofilaments as biomarkers in neurological disorders. Nat Rev Neurol 2018;14:577-589.

6. Kuhle J, Kropshofer H, Haering DA, et al. Blood neurofilament light chain as a biomarker of MS disease activity and treatment response. Neurology 2019;92: e1007-e1015.

7. Sormani MP, Haering DA, Kropshofer H, et al. Blood neurofilament light as a potential endpoint in phase 2 studies in MS. Ann Clin Transl Neurol 2019;6:1081-1089.

8. Giovannoni G, Cutter G, Sormani MP, et al. Is multiple sclerosis a length-dependent central axonopathy? The case for therapeutic lag and the asynchronous progressive MS hypotheses. Mult Scler Relat Disord 2017;12:70-78. 


\title{
Neurology \\ Neuroimmunology \& Neuroinflammation
}

\author{
Blood neurofilament light chain at the doorstep of clinical application \\ David Leppert and Jens Kuhle \\ Neurol Neuroimmunol Neuroinflamm 2019;6; \\ DOI 10.1212/NXI.0000000000000599
}

This information is current as of August 9, 2019

\section{Updated Information \& Services}

\section{References}

Citations

Subspecialty Collections

Permissions \& Licensing

Reprints including high resolution figures, can be found at:

http://nn.neurology.org/content/6/5/e599.full.html

This article cites 8 articles, 1 of which you can access for free at: http://nn.neurology.org/content/6/5/e599.full.html\#\#ref-list-1

This article has been cited by 4 HighWire-hosted articles: http://nn.neurology.org/content/6/5/e599.full.html\#\#otherarticles

This article, along with others on similar topics, appears in the following collection(s):

Class II

http://nn.neurology.org//cgi/collection/class_ii

Clinical trials Observational study (Cohort, Case control)

http://nn.neurology.org//cgi/collection/clinical_trials_observational_stu dy_cohort_case_control

Multiple sclerosis

http://nn.neurology.org//cgi/collection/multiple_sclerosis

Information about reproducing this article in parts (figures,tables) or in its entirety can be found online at:

http://nn.neurology.org/misc/about.xhtml\#permissions

Information about ordering reprints can be found online: http://nn.neurology.org/misc/addir.xhtml\#reprintsus

Neurol Neuroimmunol Neuroinflamm is an official journal of the American Academy of Neurology.

Published since April 2014, it is an open-access, online-only, continuous publication journal. Copyright

Copyright (C) 2019 The Author(s). Published by Wolters Kluwer Health, Inc. on behalf of the American

Academy of Neurology.. All rights reserved. Online ISSN: 2332-7812.

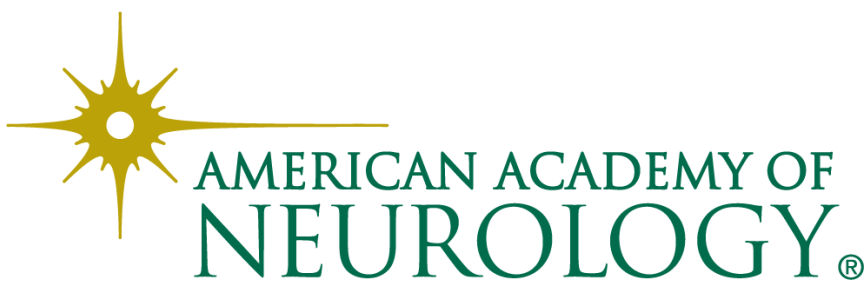

